\title{
Migration of Japanese temperate bass Lateolabrax japonicus juveniles within the Chikugo River estuary revealed by $\delta^{13} \mathrm{C}$ analysis
}

\author{
Keita W. Suzuki ${ }^{1, *}$, Akihide Kasai ${ }^{1}$, Taro Ohta ${ }^{2}$, Kouji Nakayama $^{3}$, Masaru Tanaka ${ }^{3}$ \\ ${ }^{1}$ Division of Applied Biosciences, Graduate School of Agriculture, Kyoto University, Oiwake-cho, Kitashirakawa, Sakyo-ku, \\ Kyoto 606-8502, Japan \\ ${ }^{2}$ Tottori Prefectural Fisheries Research Center, Ishiwaki, Yurihama-cho, Tottori 689-0602, Japan \\ ${ }^{3}$ Field Science Education and Research Center, Kyoto University, Oiwake-cho, Kitashirakawa, Sakyo-ku, \\ Kyoto 606-8502, Japan
}

\begin{abstract}
With conventional techniques it is difficult to evaluate the nursery value for migratory juveniles of Japanese temperate bass Lateolabrax japonicus within the Chikugo River estuary in Japan, especially in lower salinity areas where highly abundant prey organisms are distributed. In the present study stable carbon isotope ratios $\left(\delta^{13} C\right)$ were used as a migration tracer within the estuary. Based on preparatory information from diet-switch experiments and field observations of prey organisms, the ranges on which tissue $\delta^{13} \mathrm{C}$ values of juveniles should converge (convergence range) were determined in lower and higher salinity areas (LSA salinity $<10$, HSA salinity $>10$ ). For early juveniles, muscle $\delta^{13} \mathrm{C}$ values were analyzed and ages were determined by otolith increment counts. For more developed juveniles $\delta^{13} \mathrm{C}$ values were analyzed in muscle and liver, whose half-life values were 11.4 and $2.9 \mathrm{~d}$, respectively. Temporal patterns of migration were estimated by comparing $\delta^{13} \mathrm{C}$ values in muscle and liver with the convergence ranges of both LSA and HSA. Early juveniles aggregated around the river mouth in March 2003 and the majority gradually ascended the river to LSA by April. Most of them stayed in LSA until August, while some began to expand their home ranges to HSA after July. In addition, it is suggested that the timing of ascent influenced the early growth of juveniles. Consequently, the potential importance of LSA was demonstrated during the first growth season of Japanese temperate bass in the estuary.
\end{abstract}

KEY WORDS: Migration $\cdot$ Stable isotopes $\cdot$ Estuary $\cdot$ Salinity $\cdot$ Fish $\cdot$ Muscle $\cdot$ Liver $\cdot$ Otolith

\section{INTRODUCTION}

Estuaries tend to have several heterogeneous habitat types - with a range of physical and biological proproperties - which as a whole have been considered a nursery for migratory fish and invertebrates from the sea (Beck et al. 2001). Many species migrate among such habitats to meet their life stage needs. Beck et al. (2001) urged that nursery quality should be compared among specific habitats for a better understanding of estuarine ecology and effective conservation of estuarine ecosystems. Consequently, it is important to evalu- ate the quality of specific habitats and to elucidate the significance of migration among habitats within an estuary. The knowledge of detailed migration patterns is fundamental to such studies.

To date the distribution of larval fish and prey zooplankton has been surveyed on spatial and temporal scales in relation to physical mechanisms in estuaries; for example, the St. Lawrence River estuary (e.g. Dauvin \& Dodson 1990, Laprise \& Dodson 1994) Chesapeake Bay estuary (e.g. North \& Houde 2001, 2003). As a result of these studies it has been inferred that the estuarine turbidity maximum (ETM) in the low salinity 
area possesses advantageous properties as a fish nursery, providing high concentrations of prey zooplankton and potential refuges from visual predators. However, there have only been a few studies that have succeeded in evaluating the quality of the ETM and/or other estuarine habitats for specific fish species (Kraus \& Secor 2004, 2005) due to difficulties in characterizing the migratory records of individuals within an estuary before estimating life-history parameters (e.g. growth, survival and reproduction rates).

The Japanese temperate bass Lateolabrax japonicus is a euryhaline marine fish of commercial importance that inhabits the coastal areas of Japan and Korea. In the Chikugo River estuary of the Ariake Sea on Kyushu Island, Japan, variations in migratory pathways for simultaneously occurring juveniles have been reported: some migrate upstream to the upper estuary, while others reside in the lower estuary (Matsumiya et al. 1982, 1985) or the littoral zone (Hibino et al. 2002, 2006). For early juveniles of Japanese temperate bass, upstream migration has never been reported anywhere in Japan except for the Ariake Sea. The ETM of the upper Chikugo River estuary is also known to be abundant in prey organisms (Hibino et al. 1999, Islam et al. 2005, 2006). These studies suggested that upstream migration to the ETM would promote recruitment success of early juveniles. Using microprobe analyses of otolith $\mathrm{Sr}$ and Ca, Ohta et al. (1997) and Secor et al. (1998) detected evidence of ingress into freshwater during early life stages of Japanese temperate bass in the Ariake Sea. Unfortunately, the ingress into brackish water from seawater could not be detected because the otolith $\mathrm{Sr} / \mathrm{Ca}$ ratio of Japanese temperate bass only falls significantly in otoliths exposed to freshwater (salinity 0; Ohta et al. 1997). Therefore, the next challenging issue is revealing detailed patterns of both ingress and residence in the ETM of the low salinity area.

In recent years stable isotopes have been used successfully in studies tracking animal (reviewed in Hobson 1999) and fish migration (reviewed in Herzka 2005). Generally, animal tissues reflect the stable carbon isotope ratios of their organic sources (DeNiro \& Epstein 1978). In aquatic ecosystems the respective organic sources along salinity gradients tend to have distinctive stable carbon isotope ratios (Fry \& Sherr 1984). After migration stable isotope ratios in animal tissues gradually converge on the value that reflects new organic sources. Before this convergence has been attained recent immigrants can be distinguished from residents, individuals that have inhabited the sampling site for a relatively longer period, by comparison of the stable isotope ratios. Moreover, it is possible to estimate the habitat before migration and the elapsed time after migration using the information about isotopic changes in animal tissues that can be obtained from laboratory experiments (e.g. Fry \& Arnold 1982, Fry 1983, Herzka \& Holt 2000, Herzka et al. 2001, 2002).

To characterize temporal patterns of change in stable isotope ratios from different tissues that have respective metabolic rates, diet-switch experiments would be necessary before field application. Suzuki et al. (2005) reported that stable isotope ratios changed at tissuespecific rates and converged on tissue-specific values reflecting respective diets in a diet-switch experiment using Japanese temperate bass juveniles. As a next step we confirmed that prey organisms for Japanese temperate bass juveniles in the Chikugo River estuary had distinctive stable carbon isotope ratios in each salinity range: the lower the salinity, the more depleted the stable carbon isotope ratios (Suzuki et al. in press). Based on prerequisite information obtained in these studies, stable carbon isotope ratios were introduced as a practical tracer for migration. The objective of this study was to demonstrate temporal migration patterns of Japanese temperate bass juveniles within the Chikugo River estuary, especially in the low salinity area. The relationship between migration and growth in spring was determined for early juveniles by establishing migratory histories recorded in stable carbon isotope ratios and ages recorded in otolith micro-structural increments. Detailed migratory histories of more developed juveniles in summer were reconstructed using stable carbon isotope ratios of both muscle (longterm records) and liver (short-term records).

\section{MATERIALS AND METHODS}

Study site. Field collections were conducted along the lower reaches and the tidal way of the Chikugo River, the largest river flowing into the Ariake Sea, during the spring-summer season of 2003. The Chikugo River estuary is characterized by macro-tidal influences; during spring tide, tidal amplitudes and turbidity exceed $4 \mathrm{~m}$ and $200 \mathrm{NTU}$, respectively (Shoji et al. 2006a). Six stations (R1 to R6) were set up along the lower reaches of the river, ranging from the mouth of the river to $19 \mathrm{~km}$ upstream (Fig. 1). Three stations (E1 to E3) were set up along the tidal way of the river in such a way that E1 was near the mouth of the river and E3 was at the edge of the tidal flat (Fig. 1). All stations except the 2 uppermost were the same as 7 stations employed in previous studies (e.g. Matsumiya et al. 1982, 1985). Since the ETM is usually found in the lower salinity area $(<10)$ and transported back and forth over a $20 \mathrm{~km}$ range along the estuary during spring tides (Shirota \& Tanaka 1981), spatial distributions within the estuary could be more easily understood in relation to salinities than stations. 


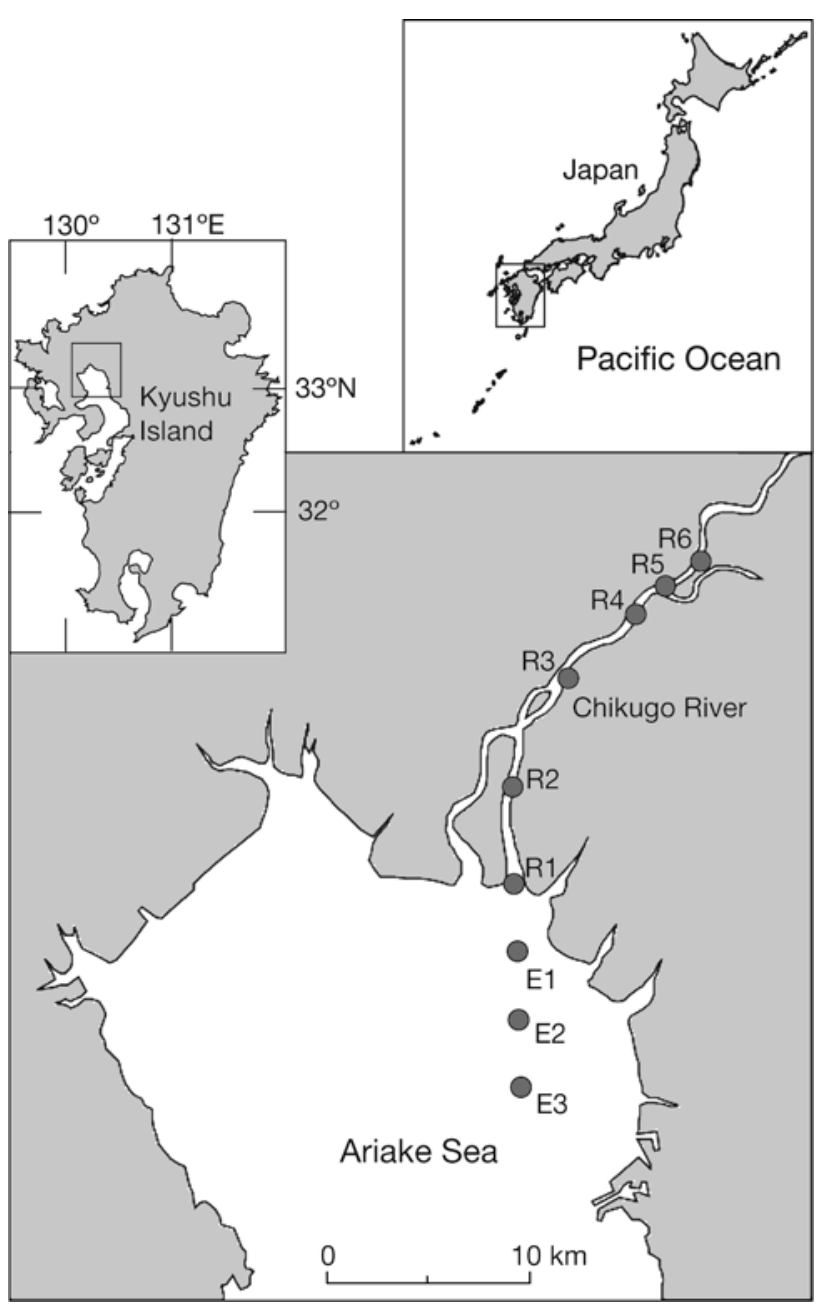

Fig. 1. Sampling stations along the Chikugo River estuary of the Ariake Sea on Kyushu Island, Japan

Field sampling. In order to collect early juveniles of Japanese temperate bass, ring-net hauls, along with environmental surveys, were conducted at 7 stations (R4 to E3; see Fig. 1) on 18 March, 15 April, 15 May, 16 June, 16 July and 13 August 2003. All of the sampling dates corresponded with spring tides. A ring net (1.3 m mouth diameter, $1 \mathrm{~mm}$ mesh aperture along a $3.5 \mathrm{~m}$ cylindrical body, and $0.33 \mathrm{~mm}$ mesh aperture at the $1.5 \mathrm{~m}$ conical end) equipped with a flow meter was towed by boat in the surface water for $10 \mathrm{~min}$ at $3.7 \mathrm{~km} \mathrm{~h}^{-1}$ against the tidal flow. Surface water temperature and salinity were measured with an environmental monitoring system (YSI 650 MDS, YSI). Hauls and surveys were started from the upper station and were finished within 4 to $5 \mathrm{~h}$ around the high slack tide in the morning. At the 2 uppermost stations (R6 and R5), additional hauls and surveys were conducted on 14 April, when some juveniles were expected to reach the uppermost estuary (Matsumiya et al. 1982, 1985).
In June hauls were conducted at only 4 stations (R4, R3, R1 and E3).

To collect more developed juveniles (hereafter termed late juveniles) 'Shige ami' fishing — one of the traditional methods in the Ariake Sea - was operated at R4 and E1 on 14 May, 15 June, 15 July and 12 August 2003. The Shige ami method involves collecting fish from an anchored boat using a net. The fish that swim with the tidal flow are trapped by a net fixed to the bow of the boat. Trapped fish were collected every $5 \mathrm{~min}$ by a dip net and surface water temperature and salinity were measured every $10 \mathrm{~min}$. Since each station was fished using Shige ami for $2 \mathrm{~h}$ during the ebb tide, the salinity dropped with time, especially at E1. This enabled the collection of fish from relatively wide salinity ranges at each station ( 0.2 to 2.5 at $\mathrm{R} 4$ and 0.4 to 25.6 at E1; Suzuki et al. in press).

Japanese temperate bass juveniles were sorted and frozen onboard. Potential prey organisms for juveniles were sorted from the ring-net hauls. In addition, they were collected by vertical and horizontal hauls of a plankton net $(45 \mathrm{~cm}$ mouth diameter, $1 \mathrm{~m}$ long, $0.1 \mathrm{~mm}$ mesh aperture). They were also frozen onboard. These samples were transported to the laboratory and kept frozen until further analyses. Full catches from ring-net hauls were preserved onboard in $10 \%$ formalin in order to study the distribution of prey organisms.

Laboratory analysis. The standard body length (SL) and wet body weight (BW) of all Japanese temperate bass individuals were measured with the exception of 4 injured individuals collected in March. For age determination of early juveniles, otoliths were removed, embedded in epoxy resin on glass slides and polished with fine sandpaper until core regions appeared and were clear. Lapilli were used because they were subject to fewer sub-daily increments and peripheral primordia than sagittae for individuals of ca. 20 to $30 \mathrm{~mm}$ SL. Up to 20 randomly selected juveniles from each sampling station in March (140 ind.) and all juveniles collected in April (189 ind.) were analyzed. All growth increments from the core to the margin were counted 3 times under a microscope (magnification of 400 to $1000 \times$ ) equipped with a video monitoring system. As a rule the left lapilli were analyzed by a single researcher and mean values from 3 counts were adopted (coefficient of variance <0.05). If left lapilli were unavailable owing to loss, breakage, or staining, right lapilli were used.

For stable isotope analyses, lateral white muscle anterior to the dorsal fin was excised from juveniles collected from April to August. In addition, whole liver was excised from late juveniles collected from June to August. Unfortunately, the early juveniles collected in March were too small to obtain sufficient amounts of muscle tissue. Similarly, the early juveniles in April and 
May were too small to obtain liver tissue. All individuals (April and August) and randomly selected individuals (May to July) were used for stable isotope analyses. Frozen samples of tissues and prey organisms from the environment were dried at $60^{\circ} \mathrm{C}$ for $>24 \mathrm{~h}$. After being ground to a fine powder, samples were weighed and placed into tin containers without lipid removal. Carbon stable isotope ratios were determined using a stable isotope ratio mass spectrometer (Delta S, Finnigan MAT) in continuous-flow mode, equipped with an elemental analyzer (EA1108, Fisons Instrument).

Stable isotope ratios were described by parts per thousand (\%) deviations from the international standard using:

$$
\delta^{13} \mathrm{C}=\left[\left(R_{\text {sample }} / R_{\text {standard }}\right)-1\right] \times 1000
$$

where $R$ is the ${ }^{13} \mathrm{C} /{ }^{12} \mathrm{C}$ ratio. Pee Dee Belemnite was used as the standard and DL-alanine as a secondary standard to verify the accuracy of stable isotope analyses. SDs for the secondary standard were $<0.1 \%$.

With respect to sampling campaigns conducted along the Chikugo River estuary in 2003, Suzuki et al. (in press) have documented that Japanese temperate bass juveniles ontogenetically changed prey organisms from copepods in spring (March and April) to mysids and decapods in summer (May to August). Among the copepod species Sinocalanus sinensis was overwhelmingly dominant at lower salinities, while Acartia omorii was relatively dominant at higher salinities. Copepod assemblages and physical properties during the spring of 2003 have also been reported (Islam et al. 2005). In order to know the distribution of important prey organisms in summer, the mysid Acanthomysis longirostris and decapod Acetes japonicus were identified and quantitatively counted using samples from ring-net hauls preserved in $10 \%$ formalin.

Data analysis. To compare physical and biological properties (Hibino et al. 1999, Islam et al. 2005, Shoji et al. 2006a, Suzuki et al. in press), we divided the Chikugo River estuary between higher and lower salinity areas (HSA salinity $>10$, LSA salinity $<10$ ) (Table 1). In HSA composite assemblages, including euryhaline-coastal copepods (e.g. Acartia omorii, Paracalanus parvus and Oithona davisae) and the pelagic decapod Acetes japonicus were observed. In contrast, a mono-specific assemblage mainly consisted of the true-estuarine copepod Sinocalanus sinensis and the mysid Acanthomysis longirostris in the ETM of LSA. Therefore, a salinity value of 10 was considered not as an absolute boundary but a convenient dividing line between 2 contrasting areas.
The $\delta^{13} \mathrm{C}$ ranges on which the $\delta^{13} \mathrm{C}$ values of fish tissues should converge during long-term residence (hereafter, convergence ranges) were predicted by adding trophic enrichment ranges to mean $\delta^{13} \mathrm{C}$ values of important prey organisms for respective seasons (spring or summer) and salinity areas (HSA or LSA). The ranges of trophic enrichment used for muscle and liver were $+2.0 \pm 0.5 \%$ and $0.0 \pm 1.0 \%$, respectively. They were set to cover differential values of trophic enrichment observed in diet-switch experiments (Suzuki et al. 2005, K. W. Suzuki et al. unpubl. data). The $\delta^{13} \mathrm{C}$ values of important prey organisms were predictable from salinities where respective species were distributed: a positive linear correlation between $\delta^{13} \mathrm{C}$ and salinity in LSA and a ceiling of $\delta^{13} \mathrm{C}$ in HSA (Suzuki et al. in press). In spring convergence ranges for muscle were $-18.2 \pm 0.5 \%$ and $-25.4 \pm 0.5 \%$ in HSA and LSA, respectively, because the important prey organisms were 2 copepod species, Acartia omorii $(-20.2 \%)$ and Sinocalanus sinensis $(-27.4 \%$ ) in HSA and LSA, respectively (Table 2). In summer the mysid Acanthomysis longirostris $(-22.2 \%)$ and the decapod Acetes japonicus (-18.1\%) were important. Convergence ranges were, therefore, $-20.2 \pm 2.0 \%$ and $-16.1 \pm 0.5 \%$ for muscle in LSA and HSA, respectively, and $-22.2 \pm 2.0 \%$ and $-18.1 \pm 1.0 \%$ for liver in LSA and HSA, respectively (Table 2). Relatively wide convergence ranges $( \pm 2.0 \%$ ) were predicted for LSA in summer due to the large fluctuations in the $\delta^{13} \mathrm{C}$ of A. longirostris $(\mathrm{SD}=1.9 \%)$.

Since growth rates mainly controlled isotopic changes in fish tissues (e.g. Watanabe et al. 2005), it was necessary to compare growth rates between experimental and wild juveniles before applying experimental half-life values (HL) of $\delta^{13} \mathrm{C}$ to wild juveniles (Suzuki et al. 2005). An exponential growth model was fitted to the BW increase observed in the wild juveniles collected in the summer:

$$
\mathrm{BW}_{t}=\mathrm{BW}_{\mathrm{i}} \exp (k t)
$$

Table 1. Physical and biological properties of the higher (HSA) and lower (LSA) salinity areas in the Chikugo River estuary. Salinity 10 was adopted as the dividing line in the present study

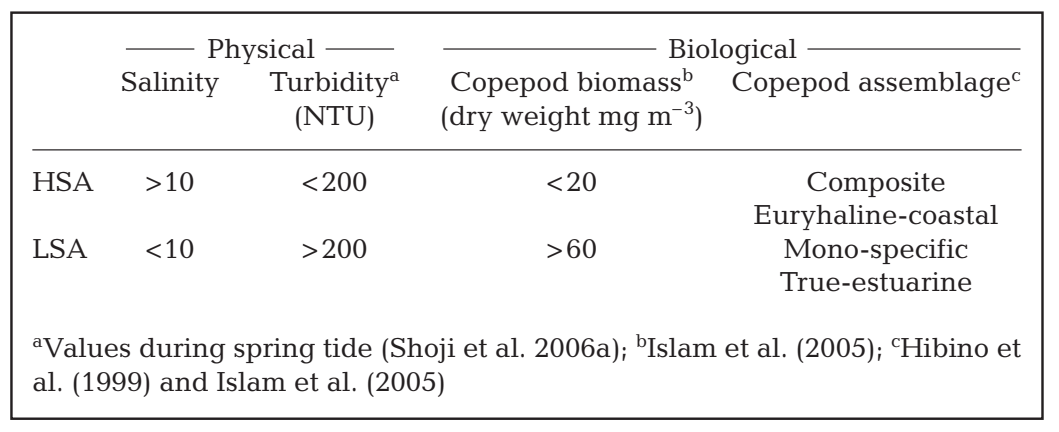


Table 2. Stable carbon isotope ratios $\left(\delta^{13} \mathrm{C}\right)$ of important prey organisms (analyzed) and Japanese temperate bass Lateolabrax japonicus juveniles (predicted). $\delta^{13} \mathrm{C}$ data are mean $\pm \mathrm{SD}(\mathrm{N})$. Samples were collected monthly at different salinities in the Chikugo River estuary in 2003. The $\delta^{13} \mathrm{C}$ ranges on which the $\delta^{13} \mathrm{C}$ values of fish tissues should converge during long-term residence were predicted by adding trophic enrichment ranges (Muscle, $+2.0 \pm 0.5 \%$; Liver, $0.0 \pm 1.0 \%$; Suzuki et al. 2005) to mean $\delta^{13} \mathrm{C}$ values (M) of respective prey species

\begin{tabular}{|c|c|c|c|c|c|}
\hline \multirow[t]{2}{*}{ Species } & \multicolumn{3}{|c|}{ Important prey organism (analyzed) } & \multicolumn{2}{|c|}{ Japanese temperate bass (predicted) } \\
\hline & Salinity & Month & $\begin{array}{c}\text { Prey } \delta^{13} \mathrm{C} \\
(\% \circ)\end{array}$ & $\begin{array}{c}\text { Muscle } \delta^{13} \mathrm{C} \\
(\mathrm{M}+2.0 \pm 0.5 \%)\end{array}$ & $\begin{array}{l}\text { Liver } \delta^{13} \mathrm{C} \\
(\mathrm{M} \pm 1.0 \% \text { o })\end{array}$ \\
\hline Acartia omorii (Copepod) & $>10$ & Mar, Apr & $-20.2(\mathrm{~N}=2)$ & $-18.2 \pm 0.5$ & $-20.2 \pm 1.0$ \\
\hline Sinocalanus sinensis (Copepod) & $<10$ & Mar-May & $-27.4 \pm 0.1(\mathrm{~N}=3)$ & $-25.4 \pm 0.5$ & $-27.4 \pm 1.0$ \\
\hline Acanthomysis longirostris (Mysid) & $<10$ & May-Aug & $-22.2 \pm 1.9(\mathrm{~N}=4)$ & $-20.2 \pm 2.0^{\mathrm{a}}$ & $-22.2 \pm 2.0^{\mathrm{a}}$ \\
\hline Acetes japonicus (Decapod) & $>10$ & Jun-Aug & $-18.1 \pm 0.3(\mathrm{~N}=3)$ & $-16.1 \pm 0.5$ & $-18.1 \pm 1.0$ \\
\hline
\end{tabular}

where $\mathrm{BW}_{\mathrm{i}}$ and $\mathrm{BW}_{t}$ represent the mean $\mathrm{BW}$ values of individuals collected on the ' $\mathrm{i}$ ' initial day and $t$ days after the initial day, and $k$ is the growth rate. The $\delta^{13} \mathrm{C}$ values of fish tissue $t$ days after a diet switch $\left(\delta^{13} C_{t}\right)$ are given by exponential models in relation to BW increase (e.g. Fry \& Arnold 1982) or elapsed time (e.g. Tieszen et al. 1983):

$$
\begin{gathered}
\delta^{13} \mathrm{C}_{t}=\delta^{13} \mathrm{C}_{\mathrm{a}}+\left(\delta^{13} \mathrm{C}_{\mathrm{i}}-\delta^{13} \mathrm{C}_{\mathrm{a}}\right)\left(\mathrm{BW}_{t} / \mathrm{BW}_{\mathrm{i}}\right)^{m} \\
\delta^{13} \mathrm{C}_{t}=\delta^{13} \mathrm{C}_{\mathrm{a}}+\left(\delta^{13} \mathrm{C}_{\mathrm{i}}-\delta^{13} \mathrm{C}_{\mathrm{a}}\right) \exp (c t)
\end{gathered}
$$

where $\delta^{13} \mathrm{C}_{\mathrm{i}}$ and $\delta^{13} \mathrm{C}_{\mathrm{a}}$ represent the initial $\delta^{13} \mathrm{C}$ at the diet switch and the asymptotic $\delta^{13} \mathrm{C}$ at equilibrium with the new diet, respectively. Metabolic constant $m$ and turnover rate $c$ have the following relationship with $k$ :

$$
C=m k
$$

When $m=-1$ changes in $\delta^{13} C_{t}$ are brought about only by growth dilution without metabolic replacement. If $m<-1$ both growth and metabolism bring about the changes. In the present study the values obtained from the experiment were substituted for $\mathrm{m}$ (-1.65 and -6.55 for muscle and liver, respectively, calculated from the results in Suzuki et al. 2005). Finally, HL were calculated for wild juveniles as:

$$
\mathrm{HL}=\ln (0.5) /(m k)
$$

Results in the text were expressed as the mean \pm SD with the number of samples analyzed (N).

\section{RESULTS}

\section{Early juveniles in spring}

The mean temperature at the stations rose from $11.30 \pm 0.25^{\circ} \mathrm{C}(\mathrm{N}=7)$ in March to $15.78 \pm 0.11^{\circ} \mathrm{C}(\mathrm{N}=9)$ in April, with minimal differences between stations. In contrast, there were strong salinity gradients between R2 and R3 in both March and April (Fig. 2a). The lower
(E3 to R2, salinity > 18) and upper (R3 to R6, salinity <4) stations corresponded to HSA and LSA, respectively. We collected 309 and 189 early juveniles of Japanese temperate bass by ring-net hauls in March and April, respectively. Their sizes were $17.80 \pm 1.81 \mathrm{~mm} \mathrm{SL}$ and $0.084 \pm 0.030 \mathrm{~g} \mathrm{BW}(\mathrm{N}=305)$ in March and $20.92 \pm$ $2.25 \mathrm{~mm}$ SL and $0.149 \pm 0.055 \mathrm{~g} \mathrm{BW}(\mathrm{N}=189)$ in April.
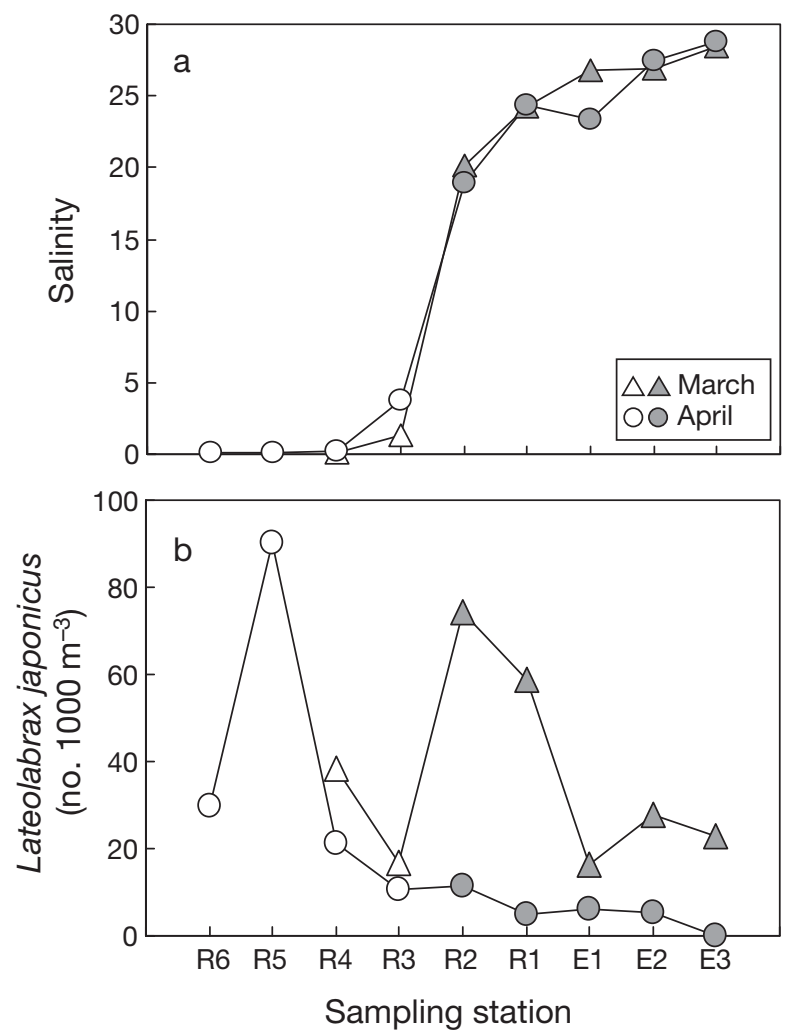

Fig. 2. (a) Surface water salinity and (b) abundances of juvenile Japanese temperate bass Lateolabrax japonicus along the Chikugo River estuary on 18 March (triangles) and 14 and 15 April (circles) in 2003. Shaded and open symbols represent the higher (>10, HSA) and lower $(<10$, LSA) salinity areas, respectively 
Juveniles were distributed throughout the estuary with a peak at R2 in March, while they were markedly concentrated at R5 in April (Fig. 2b).

Of 329 ind. used for otolith analysis, lapilli from 318 ind. were readable $(96.7 \%)$. In the present study ages of juveniles were estimated by adding 4 to the increment counts in lapilli, because the first daily increment is deposited $4 \mathrm{~d}$ after hatching (M. Matsui et al. unpubl.). One more day was added to each age for juveniles collected on 14 April in order to discuss the ages of juveniles collected on both 14 and 15 April together. Ages were $99 \pm 13 \mathrm{~d}(\mathrm{~N}=135$, range 53 to 121) and $121 \pm 12 \mathrm{~d}(\mathrm{~N}=183$, range 83 to 144) in March and April, respectively (Fig. 3).

In March the juveniles collected in LSA (19.28 \pm $1.41 \mathrm{~mm} \mathrm{SL}, 0.106 \pm 0.031 \mathrm{~g} \mathrm{BW}, \mathrm{N}=68$ ) were significantly larger and heavier than those collected in HSA $(17.38 \pm 1.69 \mathrm{~mm} \mathrm{SL}, 0.077 \pm 0.027 \mathrm{~g} \mathrm{BW}, \mathrm{N}=237$; Mann-Whitney test, $\mathrm{p}<0.01)$. Ages of juveniles in March were significantly older in LSA $(104.4 \pm 9.1 \mathrm{~d}$, $\mathrm{N}=37)$ than in HSA $(96.9 \pm 13.8 \mathrm{~d}, \mathrm{~N}=98$; MannWhitney test, $\mathrm{p}<0.01$; Fig. 3a). In April the juveniles were not significantly larger but significantly heavier in LSA $(21.05 \pm 2.32 \mathrm{~mm} \mathrm{SL}, 0.156 \pm 0.057 \mathrm{~g} \mathrm{BW}, \mathrm{N}=$ 140) than HSA $(20.58 \pm 2.04 \mathrm{~mm} \mathrm{SL}, 0.129 \pm 0.046 \mathrm{~g}$ BW, $\mathrm{N}=49$; Mann-Whitney test, $\mathrm{p}>0.05$ and $\mathrm{p}<0.01$, respectively). Ages in April were not significantly different between juveniles collected in LSA and HSA (Mann-Whitney test, $\mathrm{p}>0.05$, Fig. 3b).

Muscle $\delta^{13} \mathrm{C}$ values of juveniles collected in April ranged from -21.04 to $-16.71 \%$, being within or close to the convergence range of HSA (Fig. 4). All individuals collected in HSA had $\delta^{13} \mathrm{C}$ values within or above

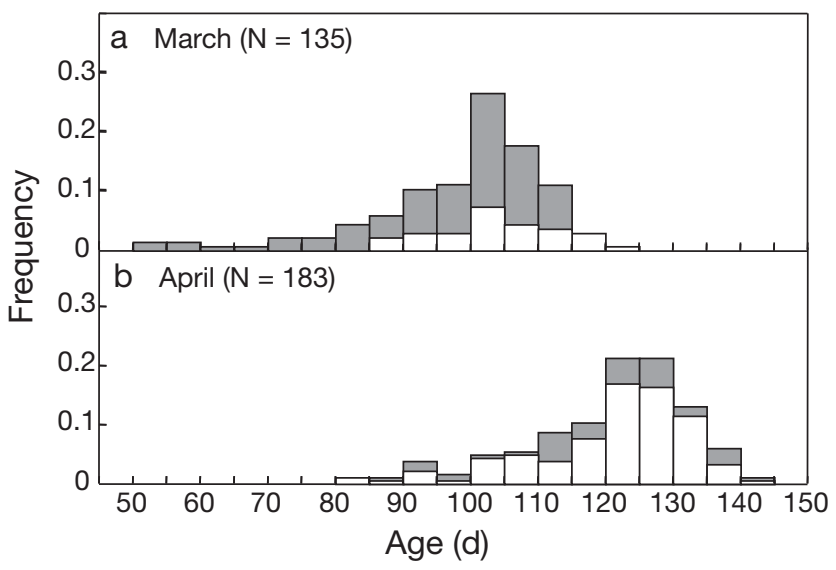

Fig. 3. Lateolabrax japonicus. Age-frequency distributions of Japanese temperate bass juveniles collected along the Chikugo River estuary on (a) 18 March and (b) 14 and 15 April 2003. The juveniles collected in the higher salinity area $(>10$, HSA, shaded bars) are shown above those collected in the lower salinity area $(<10$, LSA, open bars). N, number of individuals used for age determination

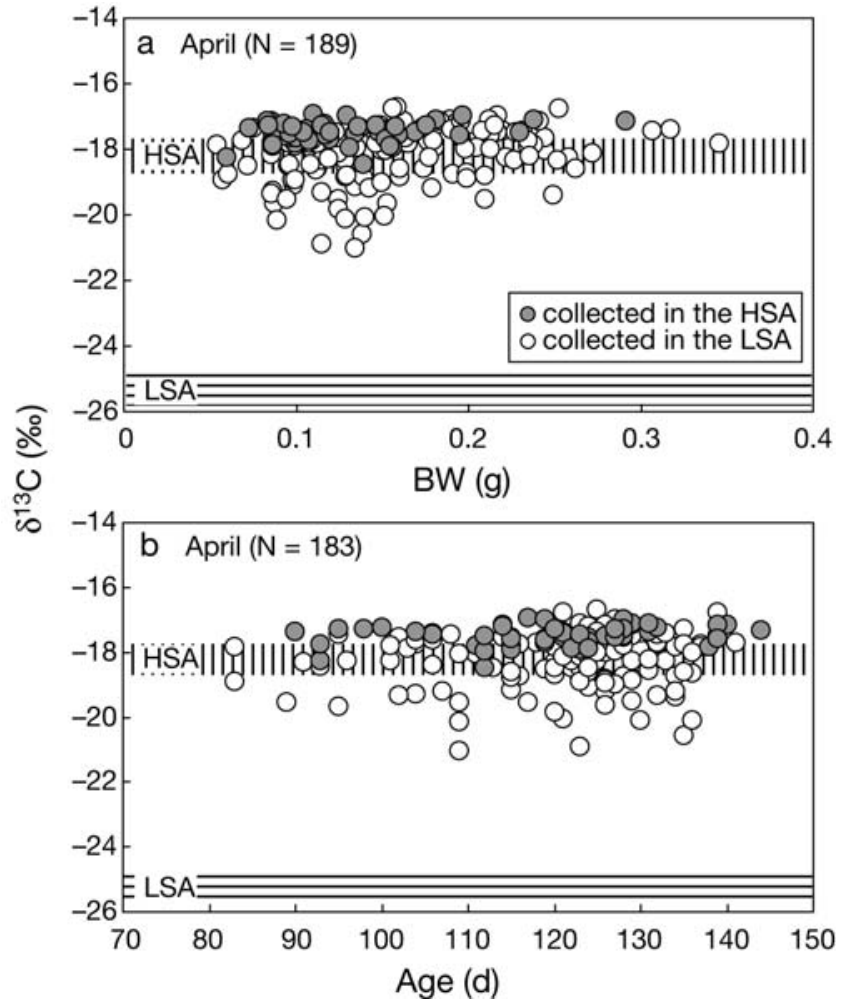

Fig. 4. Lateolabrax japonicus. Muscle $\delta^{13} \mathrm{C}$ values of Japanese temperate bass juveniles as a function of (a) wet body weight (BW) and (b) daily age. Shaded and open circles represent the juveniles collected in the higher $(>10, \mathrm{HSA})$ and lower $(<10$, LSA) salinity areas, respectively, of the Chikugo River estuary on 14 and 15 April 2003. The $\delta^{13} \mathrm{C}$ ranges, on which muscle $\delta^{13} \mathrm{C}$ values should converge in HSA and LSA (Suzuki et al. 2005, Suzuki et al. in press), are represented by vertically and horizontally striped areas, respectively. $\mathrm{N}$, number of individuals analyzed

the convergence range of HSA $(-17.50 \pm 0.32 \%, \mathrm{~N}=$ $49)$, suggesting residence in HSA. This group is hereafter termed 'residents'. Of 140 ind. collected in LSA, 107 ind. had $\delta^{13} \mathrm{C}$ values within or above the convergence range of HSA $(-17.84 \pm 0.48 \%)$. Since they were considered to be recent emigrants from HSA to LSA, they were termed 'late emigrants'. In contrast, individuals with more depleted $\delta^{13} \mathrm{C}$ values $(-19.47 \pm 0.60 \%$, $\mathrm{N}=33$ ) than the convergence range of HSA were termed 'early emigrants'. It was supposed that they would have emigrated from HSA and resided in LSA relatively earlier. Although the early and late emigrant groups were not distinctive, but continuous, it would be reasonable to use the lower limit of the convergence range of HSA (-18.76\%) as the dividing line.

To discuss the relationship between migration and growth, differences in SL, BW and age were tested among the migratory groups (Fig. 5). The late emigrants $(21.36 \pm 2.34 \mathrm{~mm} \mathrm{SL}, \mathrm{N}=107)$ were significantly 


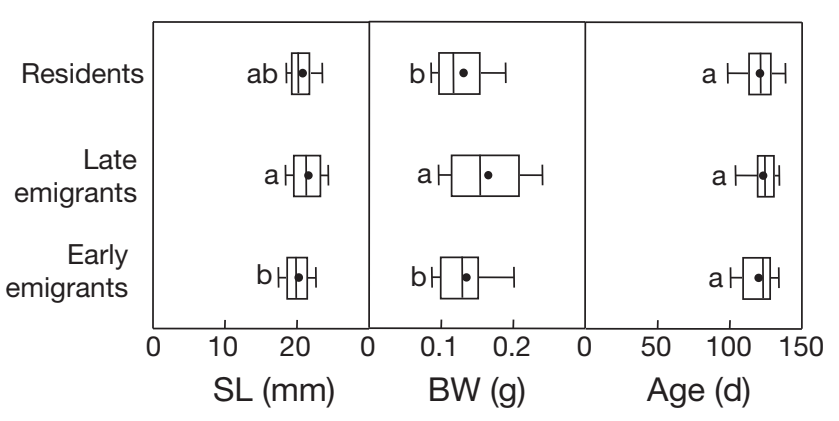

Fig. 5. Lateolabrax japonicus. Comparison of standard body length (SL), wet body weight (BW), and daily age among 3 migratory groups (residents, late emigrants and early emigrants) of Japanese temperate bass juveniles collected along the Chikugo River estuary on 14 and 15 April 2003. The residents were collected in the higher salinity area ( $>10$, HSA). The late and early emigrants were collected in the lower salinity area $(<10$, LSA) and separated according to their muscle $\delta^{13} \mathrm{C}$ values, which would indicate the relative timing of emigration from HSA. Error bars indicate the upper and lower 10 percentiles, and boxes indicate the upper and lower quartiles. Closed circles and vertical lines in the boxes indicate the means and medians, respectively. Significant differences among groups are indicated by different letters on the left of each box (post hoc test of Kruskal-Wallis test, p < 0.05)

larger than the early emigrants $(20.03 \pm 1.95 \mathrm{~mm} \mathrm{SL}$, $\mathrm{N}=33$; post hoc test of Kruskal-Wallis test, $\mathrm{p}<0.05$ ), while the residents $(20.58 \pm 2.04 \mathrm{~mm} \mathrm{SL}, \mathrm{N}=49)$ showed no significant difference from both of the emigrant groups (post hoc test of Kruskal-Wallis test, p > $0.05)$. In addition, the late emigrants $(0.163 \pm 0.059 \mathrm{~g}$, $\mathrm{N}=107$ ) were significantly heavier than the early emigrants $(0.133 \pm 0.042 \mathrm{~g}, \mathrm{~N}=33$; post hoc test of KruskalWallis test, $\mathrm{p}<0.05)$ and the residents $(0.129 \pm 0.046 \mathrm{~g}$, $\mathrm{N}=49$; post hoc test of Kruskal-Wallis test, $\mathrm{p}<0.01$ ), while the latter 2 groups were not significantly different from each other (post hoc test of Kruskal-Wallis test, $\mathrm{p}>0.05)$. In contrast, the ages of these 3 groups were not significantly different (Kruskal-Wallis test, $\mathrm{p}>0.05)$.

\section{Late juveniles in summer}

The mean temperature at the stations rose from $19.65 \pm 0.21^{\circ} \mathrm{C}(\mathrm{N}=7)$ in May to $24.44 \pm 1.19^{\circ} \mathrm{C}(\mathrm{N}=7)$ in August. Salinity gradients observed around the high slack tide were different among months (Fig. 6a). The LSA was temporarily narrowed in June when salinity was elevated owing to a reduced freshwater inflow. As for the distribution of important prey species, the mysid Acanthomysis longirostris was abundant in LSA, showing densities up to 28 and 198 ind. $\mathrm{m}^{-3}$ in May and June, respectively (Fig. 6b). The decapod Acetes japonicus was observed over a wide salinity range (1.1 to
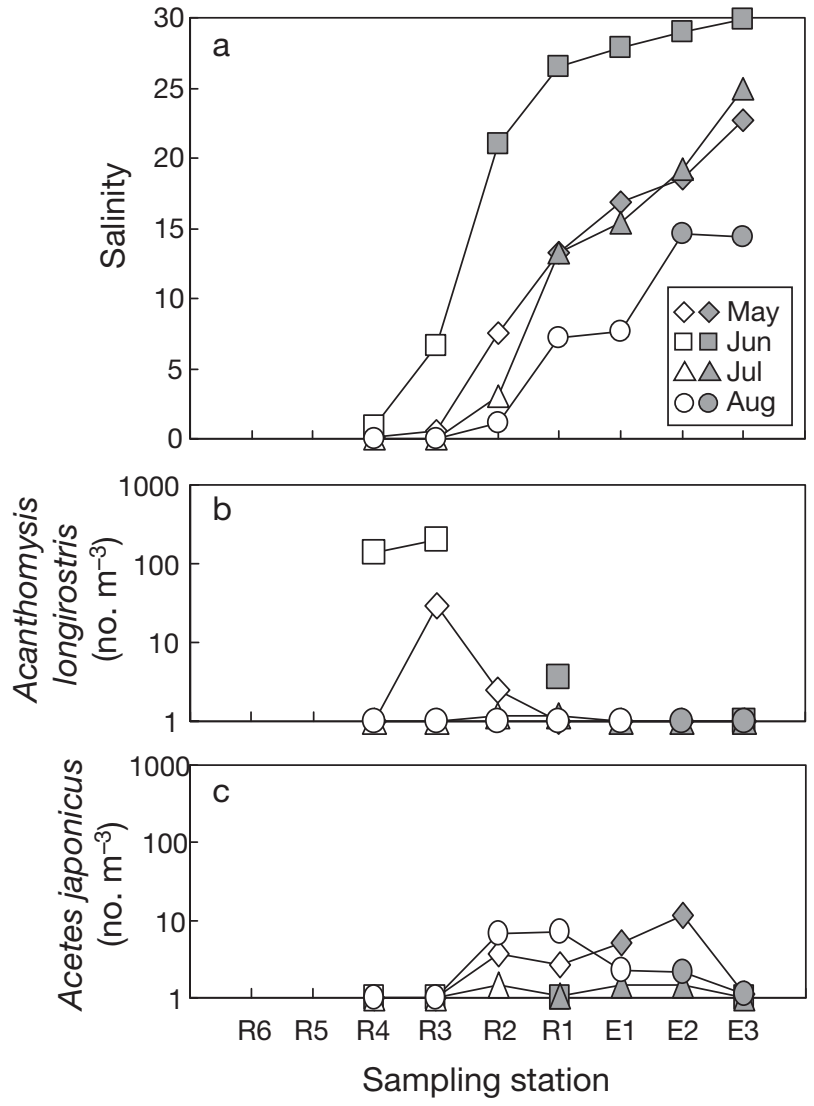

Fig. 6. (a) Surface water salinity, (b) abundances of the mysid Acanthomysis longirostris and (c) abundances of the decapod Acetes japonicus along the Chikugo River estuary on 15 May (diamonds), 16 June (squares), 16 July (triangles) and 13 August (circles) in 2003. Each abundance was logarithmically transformed after the addition of 1 . Shaded and open symbols represent the higher $(>10, \mathrm{HSA})$ and lower $(<10$, LSA) salinity areas, respectively

22.7; Fig. 6c). During all Shige ami operations, with the exception of June, salinity dropped with the ebb tide $(<0.2$ at $\mathrm{R} 4$ and $<8.9$ at E1). In June the salinity decreased from 2.5 to 1.4 at R4 and from 25.6 to 11.6 at E1.

With Shige ami fishing all of the Japanese temperate bass juveniles were collected in LSA, except for those collected at E1 in June. Those collected in HSA in June were not used for further analysis in order to compare monthly changes in LSA as rigorously as possible. In contrast to Shige ami fishing, only 21 ind. were collected by ring-net hauls from May to August. As it was presumed that these juveniles would have outgrown ring-net sampling after May, they were also not used. The length and weight of juveniles rapidly increased from May to August; mean values were $44.4 \pm 6.9 \mathrm{~mm}$ SL and $1.8 \pm 0.8 \mathrm{~g} \mathrm{BW}$ (May, $\mathrm{N}=94$ ), $65.7 \pm 8.7 \mathrm{~mm} \mathrm{SL}$ and $5.7 \pm 2.4 \mathrm{~g} \mathrm{BW}($ June, $\mathrm{N}=18$ ), 
$98.9 \pm 15.7 \mathrm{~mm}$ SL and $20.0 \pm 8.7 \mathrm{~g} \mathrm{BW}$ (July, $\mathrm{N}=63$ ) and $135.7 \pm 15.5 \mathrm{~mm}$ SL and $48.9 \pm 19.5 \mathrm{~g} \mathrm{BW}$ (August, $\mathrm{N}=20$ ). Setting the initial day as 14 May, the exponential growth model showed an excellent fit to the BW increase $\left(k=0.037, \mathrm{R}^{2}=0.99\right)$. HL of $\delta^{13} \mathrm{C}$ for the wild juveniles were calculated from Eq. (6) as 11.4 and $2.9 \mathrm{~d}$ for muscle and liver, respectively. The juveniles were randomly selected for $\delta^{13} \mathrm{C}$ analyses in May $(\mathrm{N}=40)$ and July $(\mathrm{N}=20)$; all were analyzed in June $(\mathrm{N}=18)$ and August $(\mathrm{N}=20)$.

Muscle $\delta^{13} \mathrm{C}$ values of late juveniles (Fig. $7 \mathrm{a}$ ) were scattered within or close to the convergence range of LSA in May (range -24.51 to $-17.23 \%$ ), although those of early juveniles were relatively concentrated around the convergence range of HSA. The muscle $\delta^{13} \mathrm{C}$ values were suddenly depleted in June $(-25.47$ to $-21.87 \%$ ) and enriched again in July $(-22.70$ to $-17.55 \%$ ) compared with the convergence range of LSA. In August muscle $\delta^{13} \mathrm{C}$ values were enriched $(-20.68$ to $-15.26 \%)$ toward the convergence range of

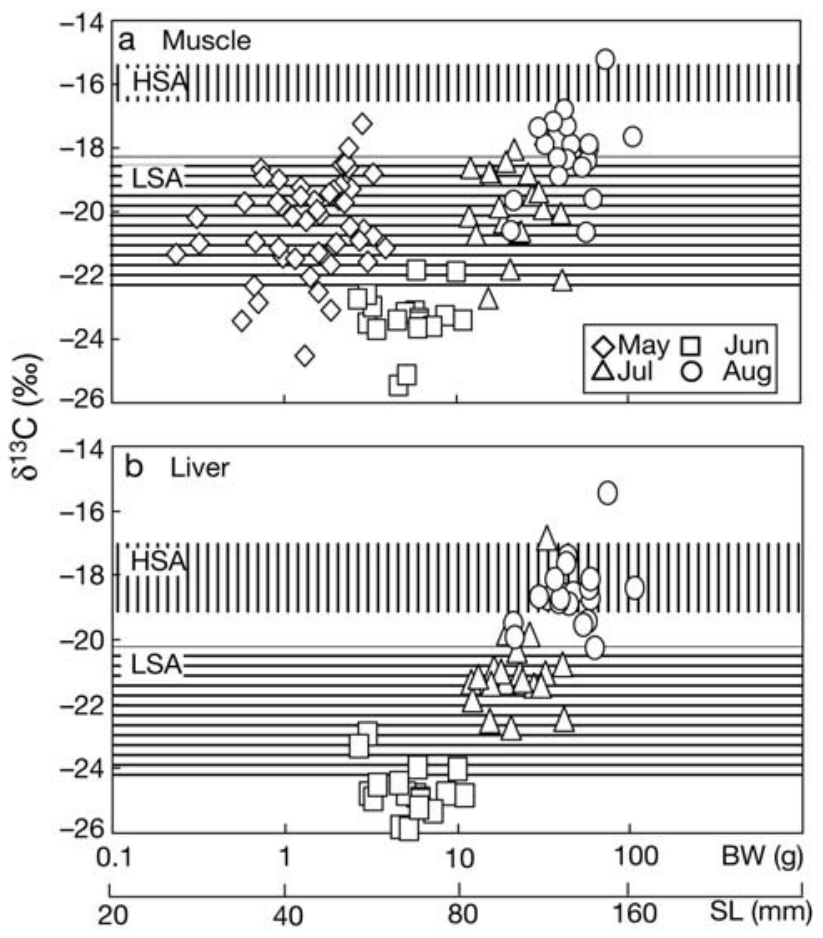

Fig. 7. Lateolabrax japonicus. $\delta^{13} \mathrm{C}$ values for (a) muscle and (b) liver from Japanese temperate bass juveniles collected in the Chikugo River estuary on 14 May (diamonds), 15 June (squares), 15 July (triangles) and 12 August (circles) in 2003. Horizontal axes represent both logarithmically transformed wet body weight (BW) and approximately calculated standard body length (SL) using the relationship between BW and SL $\left(\mathrm{BW}=38.9 \mathrm{SL}^{0.313}, \mathrm{~N}=689, \mathrm{R}^{2}=0.99\right)$. The $\delta^{13} \mathrm{C}$ ranges on which tissue $\delta^{13} \mathrm{C}$ values should converge in the higher $(>0$, HSA) and lower (<10, LSA) salinity areas (Suzuki et al. 2005, Suzuki et al. in press) are represented by vertically and horizontally striped areas, respectively
HSA, and half were outside the convergence range of LSA. Like muscle $\delta^{13} \mathrm{C}$ values, liver $\delta^{13} \mathrm{C}$ values were distributed below the convergence range of LSA in June $(-25.90$ to $-22.93 \%$; Fig. $7 b)$. Liver $\delta^{13} \mathrm{C}$ values were more enriched than muscle $\delta^{13} \mathrm{C}$ values in July $(-22.73$ to $-16.85 \%)$ and August ( -20.25 to $-15.45 \%)$.

\section{DISCUSSION}

\section{Early juveniles in spring}

In the Ariake Sea Japanese temperate bass larvae go through the pelagic stage for ca. 40 to $80 \mathrm{~d}$, transported from offshore spawning grounds to inshore nursery grounds (Shoji et al. 2006b). Some migrate to the upper estuary, while others reside in the lower estuary (Matsumiya et al. 1982, 1985) or the littoral zone (Hibino et al. 2002, 2006). The scenario that most juveniles in HSA gradually migrated into LSA in March and April, which has been inferred in previous studies, was ascertained by investigating both the spatial distribution and age structure of early juveniles in the present study (Figs. 2 \& 3). In March the majority of juveniles were distributed in HSA, while larger and older juveniles had already reached LSA, indicating a successive recruitment of younger juveniles into the estuary. Since the difference in the mean age between March and April (22 d) corresponded approximately to the sampling interval ( $28 \mathrm{~d}$ ), the cohort that was sampled in March had most likely survived and few juveniles had recruited from the sea into the estuary since March. The age difference between juveniles in LSA and HSA in March had disappeared by April. It is possible that a small number of older juveniles in LSA mingled with a large number of younger juveniles from HSA by April.

According to muscle $\delta^{13} \mathrm{C}$ values of the early juveniles collected in April, individual variations in the timing of upstream migration were revealed (Fig. 4). Although the variations were not distinctive, but continuous, the influence of timing upon early growth was tested by dividing juveniles into 3 groups (early emigrants, late emigrants and residents; Fig. 5). These 3 groups would not comprise definitive migratory groups but represent the relative timing of upstream migration from HSA. The late emigrants were significantly larger than early emigrants and heavier than both early emigrants and residents, although there were no significant differences in age. This suggests that some differences in early growth were caused by relative timing during upstream migration. As a next step it will be necessary to measure the width of otolith increments for more information about growth records. However, it is noteworthy that the early emigrants, 
which would have resided in LSA for a relatively longer period, did not show a rapid growth by April, as the ETM in LSA has been considered a better nursery habitat supplying the most important prey copepod Sinocalanus sinensis (Hibino et al. 1999, Islam et al. 2005, Shoji et al. 2006a). However, the optimal nursery area could change temporally with environmental fluctuations as well as the development of fish. An exceptionally high biomass of copepods in HSA has been observed on rare occasions, for example, in late March 2001 (Islam et al. 2006). Such an exceptional event and/or other environmental factors (e.g. temperature, Shoji et al. 2006b) might have accelerated the growth of early juveniles in HSA in 2003. Although identification of the causes of growth differences is a challenging issue for future studies, the most significant finding of the present study was a new insight into the relationship between migration and growth by comparison of the timing of upstream migration. Without stable isotope techniques, we would have come to a misleading conclusion that early juveniles in LSA always grow faster than those in HSA.

Variations in muscle $\delta^{13} \mathrm{C}$ values in April were interpreted using information about change patterns in muscle $\delta^{13} \mathrm{C}$ (i.e. relationship between isotopic change and weight increase; Suzuki et al. 2005) and $\delta^{13} \mathrm{C}$ values of prey organisms (Suzuki et al. in press). In April no juveniles had muscle $\delta^{13} \mathrm{C}$ values near the convergence range of LSA (Fig. 4), although some would have been in LSA since at least March (Fig. 2b). Because a threefold BW increase is needed to converge on the value that reflects a new diet (Suzuki et al. 2005), the slow convergence could be attributed to slow growth from March to April: the mean BW value in April was only 1.8 times heavier than that of March. Muscle $\delta^{13} \mathrm{C}$ values more enriched than the convergence range of HSA (Fig. 4) probably reflected $\delta^{13} \mathrm{C}$ contributions of not only the important prey copepod Acartia omorii (-20.26\%) but also the supplementary prey decapod larvae and chaetognaths (-19.02 and $-18.35 \%$, respectively; K. W. Suzuki et al. unpubl. data).

\section{Late juveniles in summer}

The important prey mysid Acanthomysis longirostris was markedly concentrated in LSA, while another important prey decapod Acetes japonicus was distributed over a wide salinity range from LSA to HSA (Fig. 6). A. japonicus is a euryhaline decapod with gently sloping density peaks in HSA (Fig. 6c) and occurs abundantly in the littoral zone of the inner Ariake Sea (Ikematsu 1963). Consequently, the $\delta^{13} \mathrm{C}$ values of $A$. longorostris and $A$. japonicus would represent those of prey organisms inhabiting LSA and HSA, respectively (Table 2, Suzuki et al. in press).

HL of $\delta^{13} \mathrm{C}$ were calculated as ca. 10 and $3 \mathrm{~d}$ for muscle and liver of the wild juveniles in the Chikugo River estuary, respectively. Since the size range of juveniles and water temperature observed from May to August were comparable to the conditions of the diet-switch experiments (Suzuki et al. 2005), metabolic constant values for the experimental juveniles were directly substituted for those of the wild juveniles. Given the accuracy of $\delta^{13} \mathrm{C}$ analysis and the difference in $\delta^{13} \mathrm{C}$ between HSA and LSA in summer (са. $4 \%$ o), HL were used as follows in the present study: the recent immigrants would be distinguishable from the long-term residents within twice the HL (20 and $6 \mathrm{~d}$ for muscle and liver, respectively), while beyond it they would be undistinguishable.

From May to July most of the muscle $\delta^{13} \mathrm{C}$ values were distributed within or close to the convergence range of LSA (Fig. 7a), indicating that most juveniles had stayed in LSA for $>20 \mathrm{~d}$. In August a prey shift from the mysid Acanthomysis longirostris to the decapod Acetes japonicus was suggested by intermediate values of muscle $\delta^{13} \mathrm{C}$ between the convergence ranges of LSA and HSA (Fig. 7a). Since Acetes japonicus is a euryhaline decapod species that usually occurs in HSA (Ikematsu 1963), the prey shift in August might coincide with the expansion of individual home ranges between LSA and HSA. This interpretation was supported by a close comparison of $\delta^{13} \mathrm{C}$ values between muscle and liver. While liver $\delta^{13} \mathrm{C}$ values showed a similar distribution pattern to muscle in June, the values shifted toward the convergence range of HSA in July and August (Fig. 7b). Given that changes in $\delta^{13} \mathrm{C}$ values were considerable in liver but barely perceptible in muscle, juveniles probably shifted their habitats within a relatively short period, presumably from $6 \mathrm{~d}$ (twice the HL of liver) to $10 \mathrm{~d}$ (HL of muscle). As a consequence, it would be reasonable to infer that a small proportion of individuals in July and a large proportion of individuals in August would expand their own home ranges rather than migrate in a certain direction.

Most muscle $\delta^{13} \mathrm{C}$ values in May were included in the convergence range of LSA (Fig. 7a), which corresponded to isotopic values between those estimated for the convergence ranges of HSA and LSA in April (Fig. 4). Whether muscle $\delta^{13} \mathrm{C}$ values were more depleted or more enriched before May, the rapid growth since the ontogenetic prey shift from copepods to mysids would bring about the rapid convergence on the value that reflected the $\delta^{13} \mathrm{C}$ value of the most important mysid Acanthomysis longirostris in May (Suzuki et al. in press). Indeed, mean BW values increased by 11.9 times from April to May in contrast with 1.8 times from March to April. Muscle $\delta^{13} \mathrm{C}$ values were 
more depleted than the convergence range of LSA in June (Fig. 7a). Since larger juveniles ( $>40 \mathrm{~mm} \mathrm{SL}, 1 \mathrm{~g}$ BW) seldom feed on copepods (Suzuki et al. in press), these values should not be influenced by the more depleted $\delta^{13} \mathrm{C}$ values of the copepod Sinocalanus sinensis. Although there is a possibility that the $\delta^{13} \mathrm{C}$ values of prey organisms from LSA (e.g. A. longirostris) might exceed the usual ranges with a sudden rise in salinity, more studies are needed to determine the causes of depleted muscle $\delta^{13} \mathrm{C}$ values in June.

\section{Migration revealed by $\delta^{13} \mathrm{C}$}

The migration of Japanese temperate bass juveniles within the Chikugo River estuary was documented in a schematic diagram (Fig. 8). In March early juveniles (mean age, ca. $100 \mathrm{~d}$ ) aggregated around the mouth of the river and gradually ascended the river to LSA (salinity <10). The majority reached LSA by April, while others stayed in HSA (salinity $>10$ ). In LSA the juveniles steadily gained weight, feeding on the copepod Sinocalanus sinensis until April. The juveniles stayed continuously in LSA from May to August, while some began to expand their own home ranges to HSA after July. The rapid growth is likely dependent primarily on the mysid Acanthomysis longirostris in LSA after May (Suzuki et al. in press). In the present study, it is still uncertain whether some of the juveniles stayed in HSA after April, owing to the inability to

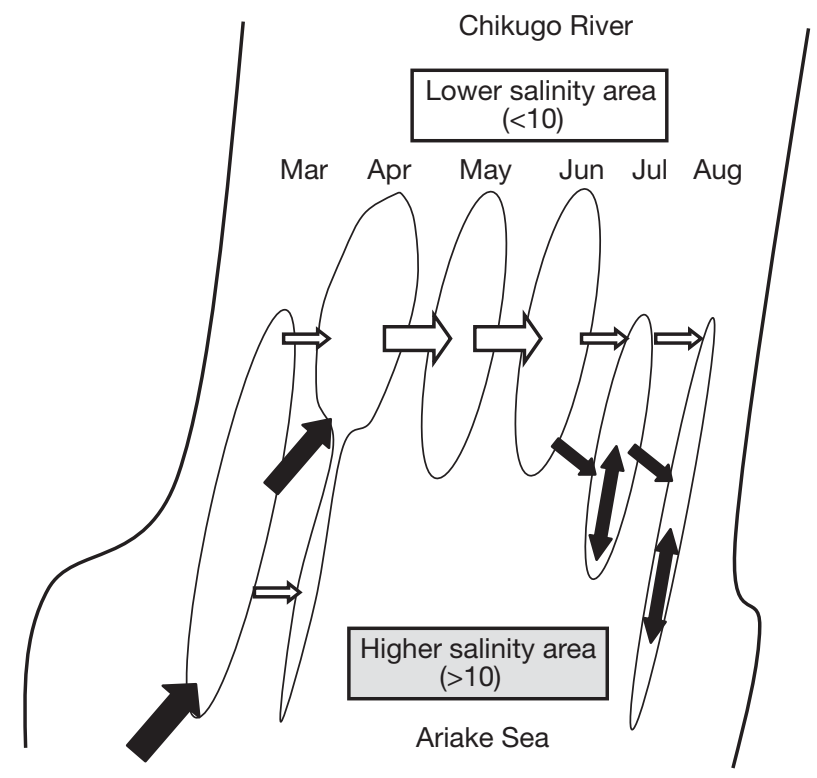

Fig. 8. Lateolabrax japonicus. Migration of Japanese temperate bass juveniles within the Chikugo River estuary. The width of ellipses represents the relative abundances of juveniles. Bold and open arrows represent migration and residence of juveniles, respectively collect late juveniles from HSA after April. However, the potential importance of LSA for the majority of juveniles in the Chikugo River estuary was demonstrated during the first growth season.

Although potential advantages in using stable isotope ratios of multiple tissues have been suggested (e.g. Tieszen et al. 1983, Phillips \& Eldridge 2006), most applications to fish ecology have been conducted without laboratory experiments or restricted to trophic studies (e.g. Sholto-Douglas et al. 1991, Gaston \& Suthers 2004). As demonstrated in the present study, stable isotope ratios of multiple tissues are practical tracers for migration if prerequisite information about the target species (e.g. trophic enrichment, HL and feeding habit) is available. The ability of tracing migration is especially important within estuaries, where the use of otolith $\mathrm{Sr}$ and $\mathrm{Ca}$ analyses is limited (Secor \& Rooker 2000) but an ecologically important habitat, the ETM, is located (e.g. Dauvin \& Dodson 1990, Laprise \& Dodson 1994, North \& Houde 2001, 2003).

The estimation of life-history parameters (e.g. growth, survival and reproduction rates) is the next step toward a better understanding of the significance of migration. Although the relationship between migration and growth was preliminarily examined by combining the stable isotope technique with others (quantitative sampling and age determination) in the present study, the integration of further pieces of information is needed for rigorous discussion. According to previous studies, the prey availability (Hibino et al. 1999, Islam et al. 2006), predation risk (Shoji et al. 2006a), river flow and temperature (Shoji et al. 2006b) would be key ecological factors in the migration of Japanese temperate bass juveniles within the Chikugo River estuary. In addition to migration within the estuary, another migratory pathway of juveniles in the littoral zone (Hibino et al. 2002, 2006), is considered significant for the population dynamics of Japanese temperate bass in the Ariake Sea. Future studies on the population will benefit considerably from a close examination of life-history parameters and key ecological factors of migratory pathways, including not only estuaries but also the littoral zones.

Acknowledgements. We express our gratitude to K. Sakemi, Kamishinden Fisheries Cooperative Association; S. Koga, Okinohata Fisheries Cooperative Association; and T. Tsukamoto, Shimochikugo Fisheries Cooperative Association, for their assistance with sample collection. We are also grateful to Dr. M. Hibino, Aichi Fisheries Promotion Fund, for his valuable advice regarding feeding habit analysis. T. Isoda, Shiga Prefectural Fisheries Experimental Station, Dr. T. Wada, and other graduate students in our laboratory also assisted with sampling in the field. Stable isotope ratios were analyzed at the Center for Ecological Research, Kyoto University. This study was supported in part by Grants-In-Aid from the Ministry of Education, Culture, Sports and Science. 


\section{LITERATURE CITED}

Beck MW, Heck KL, Able KW, Childers DL and others (2001) The identification, conservation and management of estuarine and marine nurseries for fish and invertebrates. BioScience 51:633-641

$>$ Dauvin JC, Dodson JJ (1990) Relationship between feeding incidence and vertical and longitudinal distribution of rainbow smelt larvae Osmerus mordax in a turbid wellmixed estuary. Mar Ecol Prog Ser 60:1-12

$>$ DeNiro MJ, Epstein S (1978) Influence of diet on the distribution of carbon isotopes in animals. Geochim Cosmochim Acta 42:495-506

Fry B (1983) Fish and shrimp migrations in the northern Gulf of Mexico analyzed using stable $\mathrm{C}, \mathrm{N}$, and $\mathrm{S}$ isotope ratios. Fish Bull 81:789-801

Fry B, Arnold C (1982) Rapid ${ }^{13} \mathrm{C} /{ }^{12} \mathrm{C}$ turnover during growth of brown shrimp Penaeus aztecus. Oecologia 54:200-204

Fry B, Sherr EB (1984) $\delta^{13} \mathrm{C}$ measurements as indicators of carbon flow in marine and freshwater ecosystems. Contrib Mar Sci 27:13-47

Gaston TF, Suthers IM (2004) Spatial variation in $\delta^{13} \mathrm{C}$ and $\delta^{15} \mathrm{~N}$ of liver, muscle and bone in a rocky reef planktivorous fish: the relative contribution of sewage. J Exp Mar Biol Ecol 304:17-33

Herzka SZ (2005) Assessing connectivity of estuarine fishes based on stable isotope ratio analysis. Estuar Coast Shelf Sci 64:58-69

Herzka SZ, Holt GJ (2000) Changes in isotopic composition of red drum Sciaenops ocellatus larvae in response to dietary shifts: potential applications to settlement studies. Can J Fish Aquat Sci 57:137-147

Herzka SZ, Holt SA, Holt GJ (2001) Documenting the settlement history of individual fish larvae using isotope ratios: model development and validation. J Exp Mar Biol Ecol 265:49-74

Herzka SZ, Holt SA, Holt GJ (2002) Characterization of settlement patterns of red drum Sciaenops ocellatus larvae to estuarine nursery habitat: a stable isotope approach. Mar Ecol Prog Ser 226:143-156

Hibino M, Ueda H, Tanaka M (1999) Feeding habits of Japanese temperate bass and copepod community in the Chikugo River estuary, Ariake Sea, Japan. Nippon Suisan Gakkaishi 65:1062-1068 (in Japanese with English Abstract)

Hibino M, Ohta T, Kinoshita I, Tanaka M (2002) Fish larvae and juveniles occurring in the littoral zone of a tidal flat in the bottom of Ariake Bay. Jpn J Ichthyol 49:109-120 (in Japanese with English Abstract)

Hibino M, Ohta T, Isoda T, Nakayama K, Tanaka M (2006) Diel and tidal changes in the distribution and feeding habits of Japanese temperate bass Lateolabrax japonicus juveniles in the surf zone of Ariake Bay. Ichthyol Res 53:129-136

Hobson KA (1999) Tracing origins and migration of wildlife using stable isotopes: a review. Oecologia 120:314-326

Ikematsu W (1963) Ecological studies on the fauna of Macrura and Mysidacea in the Ariake Sea. Bull Seikai Reg Fish Res Lab 30:1-124 (in Japanese with English Abstract)

Islam MS, Ueda H, Tanaka M (2005) Spatial distribution and trophic ecology of dominant copepods associated with turbidity maximum along the salinity gradient in a highly embayed estuarine system in Ariake Sea, Japan. J Exp Mar Biol Ecol 316:101-115

> Islam MS, Hibino M, Tanaka M (2006) Distribution and dietary relationships of the Japanese temperate bass Late- olabrax japonicus juveniles with two contrasting copepod assemblages in estuarine nursery grounds in the Ariake Sea, Japan. J Fish Biol 68:569-593

Kraus RT, Secor DH (2004) Dynamics of white perch Morone americana population contingents in the Patuxent River estuary, Maryland, USA. Mar Ecol Prog Ser 279:247-259

Kraus RT, Secor DH (2005) Application of the nursery-role hypothesis to an estuarine fish. Mar Ecol Prog Ser 291: 301-305

Laprise R, Dodson JJ (1994) Environmental variability as a factor controlling spatial patterns in distribution and species diversity of zooplankton in the St. Lawrence Estuary. Mar Ecol Prog Ser 107:67-81

Matsumiya Y, Mitani T, Tanaka M (1982) Changes in distribution pattern and condition coefficient of the juvenile Japanese sea bass with the Chikugo River ascending. Bull Jpn Soc Sci Fish 48:129-138

Matsumiya Y, Masumoto H, Tanaka M (1985) Ecology of ascending larval and early juvenile Japanese sea bass in the Chikugo estuary. Bull Jpn Soc Sci Fish 51:1955-1961

North EW, Houde ED (2001) Retention of white perch and striped bass larvae: biological-physical interactions in Chesapeake Bay estuarine turbidity maximum. Estuaries 24:756-769

North EW, Houde ED (2003) Linking ETM physics, zooplankton prey and fish early-life histories to striped bass Morone saxatilis and white perch $M$. americana recruitment. Mar Ecol Prog Ser 260:219-236

Ohta T, Arai N, Tanaka M (1997) Otolith Sr concentration analyzed by PIXE in Ariake estuary-dependent sea bass juveniles. Int J PIXE 7:147-151

Phillips DL, Eldridge P (2006) Estimating the timing of diet shifts using stable isotopes. Oecologia 147:195-203

Secor DH, Rooker JR (2000) Is otolith strontium a useful scalar of life cycles in estuarine fishes? Fish Res 46:359-371

Secor DH, Ohta T, Nakayama K, Tanaka M (1998) Use of otolith microanalysis to determine estuarine migrations of Japanese sea bass Lateolabrax japonicus distributed in Ariake Sea. Fish Sci 64:740-743

Shirota A, Tanaka K (1981) Studies on the suspended matter in the Ariake Bay. I. Transportation of the clay flocsuspension from the Chikugo River to the estuary. Bull Seikai Reg Fish Res Lab 56:27-38 (in Japanese with English Abstract)

Shoji J, Suzuki KW, Tanaka M (2006a) Effect of tide and river flow on physical and biological properties in the estuarine turbidity maximum of the Chikugo River estuary during spring in 2005: evaluation as a nursery for the estuarinedependent fish, Japanese sea perch Lateolabrax japonicus. Bull Jpn Soc Fish Oceanogr 70:31-38 (in Japanese with English Abstract)

Shoji J, Ohta T, Tanaka M (2006b) Effects of river flow on larval growth and survival of Japanese seaperch Lateolabrax japonicus (Pisces) in the Chikugo River estuary, upper Ariake Bay. J Fish Biol 69:1662-1674

Sholto-Douglas AD, Field JG, James AG, van der Merwe NJ (1991) ${ }^{13} \mathrm{C} /{ }^{12} \mathrm{C}$ and ${ }^{15} \mathrm{~N} /{ }^{14} \mathrm{~N}$ isotope ratios in the Southern Benguela Ecosystem: indicators of food web relationships among different size-classes of plankton and pelagic fish; differences between fish muscle and bone-collagen tissues. Mar Ecol Prog Ser 78:23-31

Suzuki KW, Kasai A, Nakayama K, Tanaka M (2005) Differential isotopic enrichment and half-life among tissues in Japanese temperate bass Lateolabrax japonicus juveniles: implications for analyzing migration. Can J Fish Aquat Sci 62:671-678 
Suzuki KW, Kasai A, Isoda T, Nakayama K, Tanaka M (in press) Distinctive stable isotope ratios in important zooplankton species in relation to estuarine salinity gradients: potential tracer of fish migration. Estuar Coast Shelf Sci (in press)

Tieszen LL, Boutton TW, Tesdahl KG, Slade NA (1983) Fractionation and turnover of stable carbon isotopes in animal

Editorial responsibility: Otto Kinne,

Oldendorf/Luhe, Germany tissues: implications for $\delta^{13} \mathrm{C}$ analysis of diet. Oecologia $57: 32-37$

Watanabe Y, Seikai T, Tominaga O (2005) Estimation of growth and food consumption in juvenile Japanese flounder Paralichthys olivaceus using carbon stable isotope ratio $\delta^{13} \mathrm{C}$ under laboratory conditions. J Exp Mar Biol Ecol 326:187-198

Submitted: February 13, 2007; Accepted: October 23, 2007 Proofs received from author(s): March 25, 2008 